\title{
Effect of Crop Geometry and Age of Seedlings on Productivity and Nutrient Uptake of Finger Millet (Eleusine coracana L. Gaertn)
}

\author{
Dibbagandla Prasanna Kumar ${ }^{* 1}$, Sagar Maitra ${ }^{1}$, Tanmoy Shankar ${ }^{1}$ and \\ Pushpalatha Ganesh ${ }^{2}$
}

\begin{abstract}
${ }^{1}$ Department of Agronomy, M.S. Swaminathan School of Agriculture, Centurion University of Technology and Management, Paralakhemundi-761 211, India

${ }^{2}$ Department of Crop Physiology \& Bio-Technology, M.S. Swaminathan School of Agriculture, Centurion University of Technology and Management, Paralakhemundi-761 211, India
\end{abstract}

*Corresponding author: 1prasannakumar64555@gmail.com (ORCID ID: 0000-0002-5875-162X)

Paper No. 791

Received: $19-04-2019$

Revised: 14-07-2019

Accepted: 24-08-2019

\begin{abstract}
Crop geometry is an important factor to achieve higher production by better utilization of resources and in turn higher production of photosynthates. The ideal crop geometry can assure healthy and uniform stand in the main field and ensure higher productivity. Proper age of seedlings has a tremendous influence on the tiller production, grain formation and other yield contributing characteristics. In view of the above, a field experiment was conducted during kharif season (June to October) of 2018 at Bagusala Farm (233' N latitude, $87^{\circ} 42^{\prime}$ E longitude) of M.S. Swaminathan School of Agriculture, Centurion University of Technology and Management, Paralakhemundi, Odisha to find out the effect of crop geometry and age of seedlings on yield attributing characters, yield and nutrient uptake of finger millet (cv. Vakula) in sandy loam soil. The experiment revealed that transplanting of 20 days old seedlings at $25 \mathrm{~cm} \times 25$ $\mathrm{cm}$ spacing registered superior performance in expression of yield attributes like effective tillers $\mathrm{m}^{-2}$, number of grain ear head ${ }^{-1}$, number of fingers ear head ${ }^{-1}$, test weight and length of the fingers; grain and straw yield and nutrient uptake. It may be concluded that to obtain higher productivity of finger millet during kharif season in sandy loam soils of south Odisha, 20 days old seedlings may be transplanted with a spacing of $25 \mathrm{~cm} \times 25 \mathrm{~cm}$.
\end{abstract}

\section{Highlights}

(0 Transplanting of 20 days old seedlings with a spacing of $25 \mathrm{~cm} \times 25 \mathrm{~cm}$ may be adopted to obtain higher productivity of finger millet

(- A planting geometry of $25 \mathrm{~cm} \times 25 \mathrm{~cm}$ spacing and 20 days old seedlings recorded greater nutrient uptake by finger millet

Keywords: Finger millet, crop geometry, age of seedling, yield attributes, yield, nutrient uptake

Finger millet (Eleusine coracana L. Gaertn) is an ecologically sound crops and not too vulnerable to risen temperature and climate change. As the crop requires very less moisture and nutrient demand, it has become a potential crop of resource poor areas. With respect to area and production in our country it has the pride of place in having the highest productivity among the millets (Seetharam and Krishne Gowda 2007). The combined potential of millets as both resilient crops for resourceconstrained farmers and as a nutritious foodstuff for growing populations, millets is slowly being rediscovered by the agricultural research and development community. Their potential for climate smart agriculture and enhanced nutrition is also underexploited. Due to these qualities it is now 
considered as a nutritious cereal in the world of escalating malnourished population and it can play a major role in nutritional security (Affholder et al. 2013; Brahmachari et al. 2018; Mishra 2019).

In India finger millet is cultivated in an area of 1.27 million ha with a production of 2.61 million $\mathrm{t}$ and productivity is $1489 \mathrm{~kg} \mathrm{ha}^{-1}$. Karnataka, Tamil Nadu, Andhra Pradesh, Orissa, Jharkhand, Uttaranchal, Maharashtra, and Gujarat are the leading states of India in finger millet cultivation. In Odisha the coverage of finger millet is in 1.66 lakh ha with a production of 1.61 lakh t (Agriculture Statistics at a Glance 2017). The average productivity of finger millet in Odisha (970 kg ha-1) is far below from the national average. Improved varieties developed in India have the production potential of $4 \mathrm{tha}^{-1}$ with proper agronomic management.

Actually, the crop is cultivated in marginal lands and fragile ecological conditions of the state. In south Odisha region, harsh and unfavorable climatic conditions coupled with poor soils make agricultural production system a gamble due to high risk of uncertainties during kharif season. Under such circumstances, it is a suitable crop to the resource poor farmers as it is an ecologically hardy crop. However, there is an urgent need to increase the productivity of finger millet as well as to achieve the maximum potential of the improved varieties. The productivity of finger millet is low due to adoption of local varieties and inferior quality seeds, poor crop stand under direct sowing, late transplanting and faulty management practices. Crop geometry is an important factor to achieve higher production by better utilization of moisture and nutrients from the soil (root spread) and above ground (plant canopy) by harvesting maximum possible solar radiation and in turn better photosynthates formation (Uphoff et al. 2011). The ideal crop geometry has to be adopted for getting optimum plant stand in the field which results in higher yield. It has been reported in Karnataka, the average yield of finger millet is more under square planting of young seedlings with single seedling hill $^{-1}$ (Kalaraju et al. 2011). Wider spacing was superior to narrow spacing in terms of enhanced grain and straw yield. Moreover, the ideal crop geometry can reduce the seed rate, healthy stand in the main field and ensure higher productivity. The age of seedlings is another important factor as it has a tremendous influence on the tiller dynamics, tiller production, grain formation and other yield contributing characteristics (Pasuquin et al., 2008). Young seedlings are transplanted to preserve the potential for high tillering and extensive rooting ability than the aged seedlings. In view of the above observations a field experiment was conducted to find out the effect of crop geometry and age of seedlings on yield attributing traits, yield and nutrient uptake of finger millet.

\section{MATERIALS AND METHODS}

The field experiment was conducted during kharif season (June to October) of 2018 at Bagusala Farm $\left(23^{\circ} 39^{\prime} \mathrm{N}\right.$ latitude, $87^{\circ} 42^{\prime} \mathrm{E}$ longitude) of M. S. Swaminathan School of Agriculture, Centurion University of Technology and Management, Paralakhemundi, Gajapati district, Odisha to evaluate the growth and productivity of finger millet as influenced by crop geometry and age of seedlings. The variety of finger millet was Vakula. In the experiment, three different crop geometries viz. $20 \mathrm{~cm} \times 20 \mathrm{~cm}, 25 \mathrm{~cm} \times 25 \mathrm{~cm}, 30 \mathrm{~cm} \times 30 \mathrm{~cm}$ and three age of seedlings viz. 15, 20 and 25 days old were considered and the treatments were as follows. $\mathbf{T}_{1}$ : Transplanting of 15 days old seedlings at $20 \mathrm{~cm} \times 20 \mathrm{~cm}, \mathbf{T}_{2}$ : Transplanting of 15 days old seedlings at $25 \mathrm{~cm} \times 25 \mathrm{~cm}, \mathrm{~T}_{3}$ : Transplanting of 15 days old seedlings at $30 \mathrm{~cm} \times 30 \mathrm{~cm}, \mathrm{~T}_{4}$ : Transplanting of 20 days old seedlings at $20 \mathrm{~cm} \times$ $20 \mathrm{~cm}, \mathrm{~T}_{5}$ : Transplanting of 20 days old seedlings at $25 \mathrm{~cm} \times 25 \mathrm{~cm}, \mathbf{T}_{6}$ : Transplanting of 20 days old seedlings at $30 \mathrm{~cm} \times 30 \mathrm{~cm}, \mathrm{~T}_{7}$ : Transplanting of 25 days old seedlings at $20 \mathrm{~cm} \times 20 \mathrm{~cm}, \mathbf{T}_{8}$ : Transplanting of 25 days old seedlings at $25 \mathrm{~cm} \times$ $25 \mathrm{~cm}, \mathrm{~T}_{9}$ : Transplanting of 25 days old seedlings at $30 \mathrm{~cm} \times 30 \mathrm{~cm}$. The raised nursery was prepared with a dimension of $4 \mathrm{~m}$ length and $1.5 \mathrm{~m}$ width. Seed sowings was done at different dates to get respective aged seedlings (15, 20 and 25 days old) to transplant on same day. Soil of the experimental field was sandy loam in texture with following physic-chemical properties (Table 1).

Table 1: Chemical properties of experimental soil

\begin{tabular}{ccccc}
\hline pH & $\begin{array}{c}\text { Organic C } \\
(\%)\end{array}$ & $\begin{array}{c}\text { Available } \\
\mathbf{N}\left(\mathbf{k g ~ h a}^{-1}\right)\end{array}$ & $\begin{array}{c}\text { Available } \\
\mathbf{P}\left(\mathbf{k g ~ h a}^{-1}\right)\end{array}$ & $\begin{array}{c}\text { Available } \\
\mathbf{K}\left(\mathbf{k g ~ h a}^{-1}\right)\end{array}$ \\
\hline 6.4 & 0.41 & 73.4 & 30.2 & 152.4 \\
\hline
\end{tabular}


Field was laid out in Randomized Complete Block Design (RCBD) with three replications. The plot size was $4 \mathrm{~m} \times 3 \mathrm{~m}$. FYM at the rate of $5 \mathrm{t} \mathrm{ha}^{-1}$ was applied to all the experimental plots uniformly before final puddling and levelling. The applied recommended dose of $\mathrm{N}, \mathrm{P}_{2} \mathrm{O}_{5}$ and $\mathrm{K}_{2} \mathrm{O}$ was $40 \mathrm{Kg}$ $\mathrm{ha}^{-1}, 20 \mathrm{Kg} \mathrm{ha}{ }^{-1}$ and $20 \mathrm{Kg} \mathrm{ha}^{-1}$ respectively. Half dose of nitrogen and full dose of phosphorous and potassium were applied at basal application just before transplanting while the remaining half dose of nitrogen was applied after 21 days after transplanting. The crop received a total rainfall $1144 \mathrm{~mm}$ during the period of experimentation. Observations on yield attributing traits, grain and straw yields were recorded and chemical analysis was done by applying the standard procedure to obtain the nutrient uptake by finger millet. The data were analyzed statistically (Panse and Sukhatme 1985) and presented.

\section{RESULTS AND DISCUSSION}

\section{Yield attributes}

The result presented in Table 2 showed that the yield attributing traits were influenced by the crop geometry and age of seedling. Yield attributing characters viz., effective tillers $\mathrm{m}^{-2}$, number of grain ear head ${ }^{-1}$, number of fingers ear head ${ }^{-1}$, test weight and length of the fingers were recorded the best with the treatment at $\mathrm{T}_{5}$ (transplanting of 20 days old seedlings at $25 \mathrm{~cm} \times 25 \mathrm{~cm}$ ) and it significantly enhanced the values of above characters. The treatment $\mathrm{T}_{5}$ (transplanting of 20 days old seedlings at $25 \mathrm{~cm} \times 25 \mathrm{~cm}$ ) being statistically at par with $\mathrm{T}_{4}$ (transplanting of 20 days old seedlings at 20 $\mathrm{cm} \times 20 \mathrm{~cm}$ ) and $\mathrm{T}_{8}$ (transplanting of 25 days old seedlings at $25 \mathrm{~cm} \times 25 \mathrm{~cm}$ ) recorded significantly more number of effective tillers $\mathrm{m}^{-2}$ and number of grains ear head ${ }^{-1}$ than all other treatments. In case of production of number of fingers ear head $1, \mathrm{~T}_{5}$ (transplanting of 20 days old seedlings at $25 \mathrm{~cm} \times 25 \mathrm{~cm}$ ) being statistically at par with $\mathrm{T}_{6}$ (transplanting of 20 days old seedlings at $30 \mathrm{~cm} \times$ $30 \mathrm{~cm}$ ) established its significant superiority over all other treatments. But test weight of finger millet of $\mathrm{T}_{5}$ (transplanting of 20 days old seedlings at $25 \mathrm{~cm} \times$ $25 \mathrm{~cm}$ ) was statistically at par with other treatments except $\mathrm{T}_{1}$ (transplanting of 15 days old seedlings at $20 \mathrm{~cm} \times 20 \mathrm{~cm}$ ). However, the length of finger of $\mathrm{T}_{5}$ (transplanting of 20 days old seedlings at 25 $\mathrm{cm} \times 25 \mathrm{~cm}$ ) was statistically at par with all other treatments tried, except $\mathrm{T}_{9}$ (transplanting of 25 days old seedlings at $30 \mathrm{~cm} \times 30 \mathrm{~cm}$ ). Treatment with a spacing of $25 \mathrm{~cm} \times 25 \mathrm{~cm}$ and medium aged $(20$ days old) seedlings $\left(\mathrm{T}_{5}\right)$ might be provided optimum spacing and congenial microclimate to crop for effective utilization of available moisture, nutrient and its early adoption for better partitioning of photosynthates to reproductive parts there by recording better yield attributes. The results are in conformity with the findings of Roy et al. (2002), Kalaraju (2011), Rajesh (2011) and Suresh (2013).

\section{Yield}

The highest grain yield of finger millet (1482 kg ha-1) was obtained with $\mathrm{T}_{5}$ (transplanting of 20 days old seedlings at $25 \mathrm{~cm} \times 25 \mathrm{~cm}$ ) which was significant over all the other treatments (Table 2 and Fig. 1).

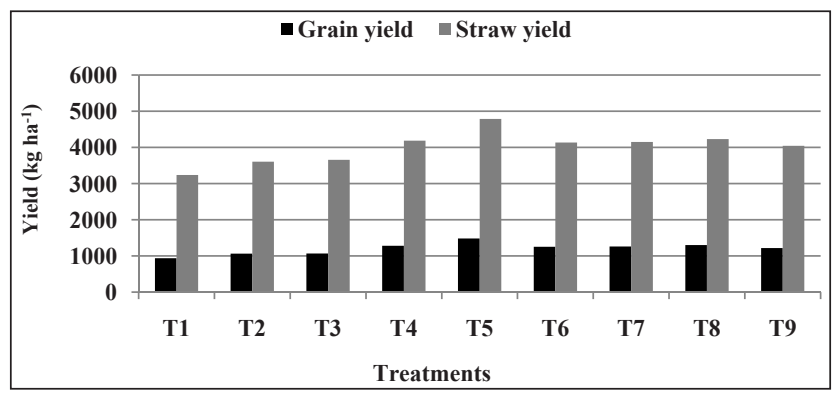

Fig. 1: Effect of crop geometry and age of seedlings on grain and straw yield of finger millet

The next best treatment was $\mathrm{T}_{8}$ (transplanting of 25 days old seedlings at $25 \mathrm{~cm} \times 25 \mathrm{~cm}$ ) which was however, comparable with $\mathrm{T}_{4}$ (transplanting of 20 days old seedlings at $20 \mathrm{~cm} \times 20 \mathrm{~cm}$ ), $\mathrm{T}_{6}$ (transplanting of 20 days old seedlings at $30 \mathrm{~cm} \times$ $30 \mathrm{~cm}$ ), $\mathrm{T}_{7}$ (transplanting of 25 days old seedlings at $20 \mathrm{~cm} \times 20 \mathrm{~cm}$ ) and $\mathrm{T}_{9}$ (transplanting of 25 days old seedlings at $30 \mathrm{~cm} \times 30 \mathrm{~cm}$ ). The lowest grain yield (936 kg ha-1) was recorded with $\mathrm{T}_{1}$ (transplanting of 15 days old seedlings at $20 \mathrm{~cm} \times$ $20 \mathrm{~cm}$ ) which remained significantly inferior to all other treatments. Maximum grain yield was noted with $\mathrm{T}_{5}$ (transplanting of 20 days old seedlings at $25 \mathrm{~cm} \times 25 \mathrm{~cm}$ ), probably because the treatment expressed comparatively more value of some yield attributing characters like effective tillers $\mathrm{m}^{2}$, number of grains per earhead ${ }^{-1}$, number of fingers earhead ${ }^{-1}$, test weight and length of the finger which are ultimately reflected into grain yield. The higher 
Table 2: Effect of crop geometry and age of seedlings on yield attributes of finger millet

\begin{tabular}{|c|c|c|c|c|c|}
\hline \multirow[b]{2}{*}{ Treatments } & \multicolumn{5}{|c|}{ Yield attributes } \\
\hline & $\begin{array}{l}\text { Effective } \\
\text { tillers } \mathbf{m}^{-2}\end{array}$ & $\begin{array}{l}\text { Number of } \\
\text { grains ear head }^{-1}\end{array}$ & $\begin{array}{c}\text { Number of } \\
\text { fingers ear } \\
\text { head }^{-1}\end{array}$ & $\begin{array}{c}\text { Test weight } \\
\text { (g) }\end{array}$ & $\begin{array}{l}\text { Length of the } \\
\text { finger }(\mathrm{cm})\end{array}$ \\
\hline $\begin{array}{l}\mathrm{T}_{1} \text { Transplanting of } 15 \text { days old seedlings at } 20 \mathrm{~cm} \\
\times 20 \mathrm{~cm}\end{array}$ & 20.6 & 1871 & 7.4 & 2.56 & 8.2 \\
\hline $\begin{array}{l}\mathrm{T}_{2} \text { Transplanting of } 15 \text { days old seedlings at } 25 \mathrm{~cm} \\
\times 25 \mathrm{~cm}\end{array}$ & 22.1 & 1892 & 7.6 & 2.60 & 8.4 \\
\hline $\begin{array}{l}\mathrm{T}_{3} \text { Transplanting of } 15 \text { days old seedlings at } 30 \mathrm{~cm} \\
\times 30 \mathrm{~cm}\end{array}$ & 21.7 & 1902 & 8.0 & 2.61 & 8.3 \\
\hline $\begin{array}{l}\mathrm{T}_{4} \text { Transplanting of } 20 \text { days old seedlings at } 20 \mathrm{~cm} \\
\times 20 \mathrm{~cm}\end{array}$ & 28.6 & 2018 & 8.3 & 2.68 & 8.3 \\
\hline $\begin{array}{l}\mathrm{T}_{5} \text { Transplanting of } 20 \text { days old seedlings at } 25 \mathrm{~cm} \\
\times 25 \mathrm{~cm}\end{array}$ & 28.8 & 2037 & 9.7 & 2.71 & 8.7 \\
\hline $\begin{array}{l}\mathrm{T}_{6} \text { Transplanting of } 20 \text { days old seedlings at } 30 \mathrm{~cm} \\
\times 30 \mathrm{~cm}\end{array}$ & 25.2 & 1907 & 9.2 & 2.63 & 8.2 \\
\hline $\begin{array}{l}\mathrm{T}_{7} \text { Transplanting of } 25 \text { days old seedlings at } 20 \mathrm{~cm} \\
\times 20 \mathrm{~cm}\end{array}$ & 24.9 & 1910 & 8.0 & 2.62 & 8.3 \\
\hline $\begin{array}{l}\mathrm{T}_{8} \text { Transplanting of } 25 \text { days old seedlings at } 25 \mathrm{~cm} \times \\
25 \mathrm{~cm}\end{array}$ & 27.3 & 2008 & 8.2 & 2.69 & 8.2 \\
\hline $\begin{array}{l}\mathrm{T}_{9} \text { Transplanting of } 25 \text { days old seedlings at } 30 \mathrm{~cm} \\
\times 30 \mathrm{~cm}\end{array}$ & 25.1 & 1912 & 8.5 & 2.62 & 8.0 \\
\hline $\mathrm{SEm} \pm$ & 0.60 & 37.81 & 0.25 & 0.06 & 0.19 \\
\hline $\mathrm{CD}(\mathrm{P}=0.05)$ & 1.80 & 112.1 & 0.75 & 0.18 & 0.58 \\
\hline CV (\%) & 5.7 & 6.3 & 9.0 & 5.7 & 7.1 \\
\hline
\end{tabular}

grain yield might be due to enhanced stature of yield attributes, thus forming larger sink size coupled with efficient translocation of photosynthates to the sink was noticed under optimum planting pattern with transplanting of medium aged seedlings $\left(\mathrm{T}_{5}\right)$. Optimum planting pattern is the prerequisite for proper utilization of growth resources and ultimately to exploit the potential productivity of any crop. The results corroborate with the findings of Kalaraju et al. (2011), Rajesh (2011) and Prakasha et al. (2018).

Different crop geometries and age of seedlings resulted in significant effect on the straw yield of finger millet. Among different crop geometry and age of seedlings tried, $\mathrm{T}_{5}$ (transplanting of 20 days old seedlings at $25 \mathrm{~cm} \times 25 \mathrm{~cm}$ ) produced significantly highest straw yield (4320 kg ha $\left.{ }^{-1}\right)$ and it recorded significantly more straw yield than all other treatments.

The increase in straw yield was probably due to adoption of planting geometry with optimum spacing and medium aged seedling for better and uniform stand which enhanced higher dry matter accumulation and this might be enhanced straw yield of finger millet. The results corroborate with the findings of Veeranna and Reddy (2010) and AICSMIP (2013). However, significant impact was not noticed in expression of harvest index.

\section{Nutrient uptake}

Crop geometries and age of seedlings have exerted significant influence on the N, P and K uptake by finger millet grain, straw and total uptake by the crop (Table 3 and Fig. 2).

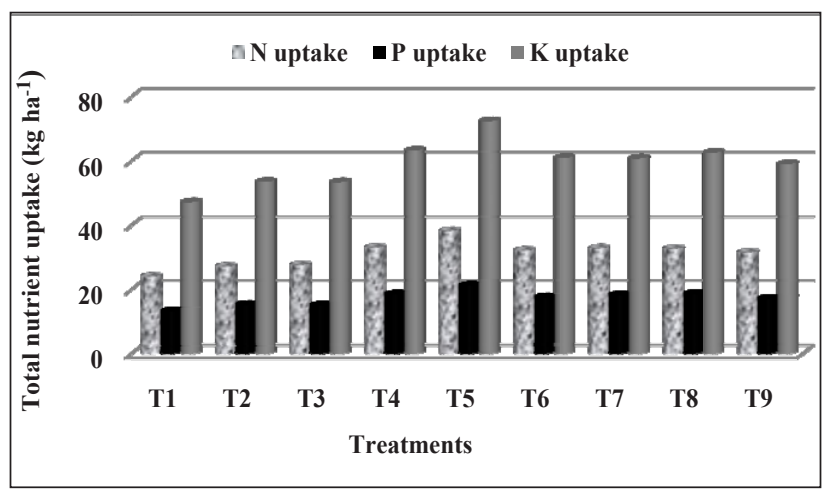

Fig. 2: Effect of crop geometry and age of seedlings on total nutrient uptake of finger millet 
Table 3: Effect of crop geometry and age of seedlings on grain and straw yield and harvest index of finger millet

\begin{tabular}{|c|c|c|c|}
\hline Treatments & $\begin{array}{l}\text { Grain yield } \\
\quad\left(\mathrm{kg} \mathrm{ha}^{-1}\right)\end{array}$ & $\begin{array}{l}\text { Straw yield } \\
\left(\mathrm{kg} \mathrm{ha}^{-1}\right)\end{array}$ & Harvest index \\
\hline $\mathrm{T}_{1}$ Transplanting of 15 days old seedlings at $20 \mathrm{~cm} \times 20 \mathrm{~cm}$ & 936 & 3238 & 22.42 \\
\hline $\mathrm{T}_{3}$ Transplanting of 15 days old seedlings at $30 \mathrm{~cm} \times 30 \mathrm{~cm}$ & 1069 & 3655 & 22.62 \\
\hline $\mathrm{T}_{4}$ Transplanting of 20 days old seedlings at $20 \mathrm{~cm} \times 20 \mathrm{~cm}$ & 1280 & 4185 & 23.42 \\
\hline $\mathrm{T}_{6}$ Transplanting of 20 days old seedlings at $30 \mathrm{~cm} \times 30 \mathrm{~cm}$ & 1253 & 4134 & 23.25 \\
\hline $\mathrm{T}_{7}$ Transplanting of 25 days old seedlings at $20 \mathrm{~cm} \times 20 \mathrm{~cm}$ & 1262 & 4151 & 23.31 \\
\hline $\mathrm{T}_{8}$ Transplanting of 25 days old seedlings at $25 \mathrm{~cm} \times 25 \mathrm{~cm}$ & 1302 & 4231 & 23.53 \\
\hline $\mathrm{T}_{9}$ Transplanting of 25 days old seedlings at $30 \mathrm{~cm} \times 30 \mathrm{~cm}$ & 1218 & 4043 & 23.15 \\
\hline SEm \pm & 32.2 & 76.4 & 0.7 \\
\hline
\end{tabular}

Table 4: Effect of crop geometry and age of seedlings on total nutrient uptake of finger millet

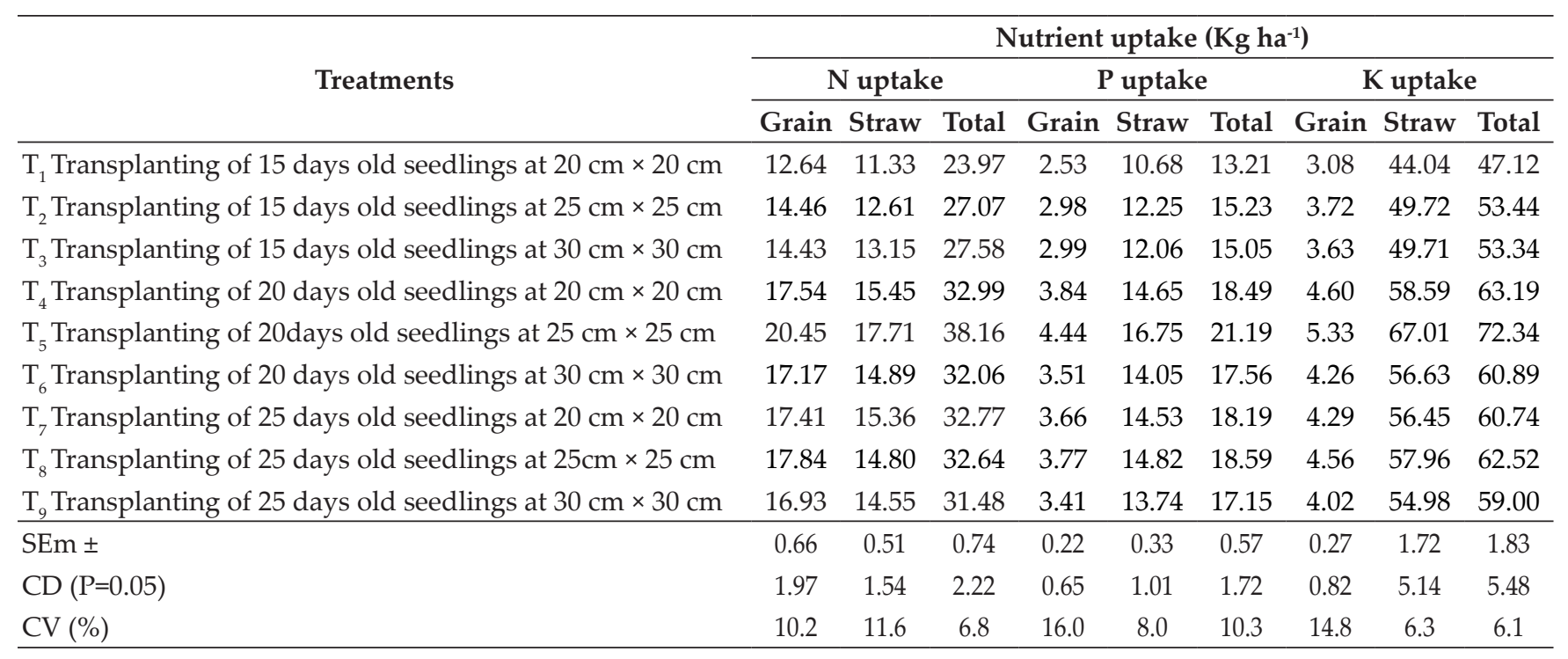

The highest nutrient uptake by the crop was recorded in $\mathrm{T}_{5}$ (transplanting of 20 days old seedlings at 25 $\mathrm{cm} \times 25 \mathrm{~cm}$ ) which was significantly superior to all other treatments tried. The lowest nutrient uptake was recorded with $\mathrm{T}_{1}$ (transplanting of 15 days old seedlings at $20 \mathrm{~cm} \times 20 \mathrm{~cm}$ ). The uptake of nutrients differed significantly among the treatments because of significant variation in grain and straw yield. The higher uptake of nutrients by grain and straw as well as total uptake of nutrients by the crop was obtained with the treatment $\mathrm{T}_{5}$ (transplanting of 20 days old seedlings at $25 \mathrm{~cm} \times 25 \mathrm{~cm}$ ) as the treatment well exhibited yield attributes and more of grain and straw yield. Such results were probably due to the impact of favorable environment and less competition among plants by optimum spacing and moderate age of seedling that assured better crop establishment. The results are in conformity with the findings of Rajesh (2011), Avasthe et al. (2012), Sri Devi and Chellamuthu (2012).

\section{CONCLUSION}

The results of the field experiment conclude that finger millet may be grown in sandy loam soils of South Odisha maintaining a spacing of $25 \mathrm{~cm} \mathrm{x}$ $25 \mathrm{~cm}$ with 20 days old seedlings to obtain more productivity and higher nutrient uptake by the crop. 


\section{ACKNOWLEDGEMENTS}

The authors are grateful to the authority of M.S. Swaminathan School of Agriculture, Centurion University of Technology and Management for funding and necessary support to carry out the experiment.

\section{DECLARATION}

The content is based on the research work carried out by the first author for partial fulfillment of M.Sc. Ag.(Agronomy) degree and there is no conflict of interest among the authors.

\section{REFERENCES}

Affholder, F., Poeydebat, C., Corbeels, M., Scopel, E. and Tittonell P. 2013. The yield gap of major food crops in family agriculture in the tropics: Assessment and analysis through field surveys and modeling. F. Crop. Res., 143: 106-118.

Agricultural Statistics at a Glance. 2017. Directorate of Economics and Statistics, Ministry of Agriculture and Farmers Welfare, Government of India.

AICSMIP (All India Co-ordinated Small Millets Improvement Project). Annual Report 2013. GKVK Campus, UAS, Bangalore, pp. AG 15-18.

Bhahmachari, K., Sarkar, S., Santra D.K. and Maitra, S. 2019. Millet for Food and Nutritional Security in Drought Prone and Red laterite Region of Eastern India. International Journal of Plant $\mathcal{E}$ Soil Science, 26(6): 1-7.

Kalaraju, K., Deva Kumar, N., Nagaraja, N. and Ningappa, K.B. 2011. Effect of methods of planting on growth and yield of finger millet genotypes under organic farming. Research on Crops, 10(1): 20-24.

Mishra, K. 2019. Yield gap analysis of finger millet through front line demonstration. International Journal of Chemical Studies, 7(1): 842-844.
Panse, V.G. and Sukhatme, P.V. 1985. Statistical methods for Agricultural workers, ICAR, New Delhi.

Pasuquin, E., Lafarge, T and Tubana, B. 2008. Transplanting young seedlings in irrigated rice field: Early and high tiller production enchanced grain yield. Field Crops Research, 105: 141-155.

Prakasha, G., Kalyana Murthy, K.N., Prathima A.S. and Rohani N.M. 2018. Effect of Spacing and Nutrient Levels on Growth Attributes and Yield of Finger Millet (Eleusine coracana L. Gaertn) Cultivated under Guni Planting Method in Red Sandy Loamy Soil of Karnataka, India. International Journal of Current Microbiology and Applied Sciences, 7(05): 1337-1343.

Rajesh, K. 2011. System of crop intensification in finger millet (Eleusine coracana (L.) Gaertn) under irrigated condition. M. Sc. (Ag.) Thesis, TNAU, Coimbatore.

Roy, N.R., Chakraborty, T., Sounda, G. and Maitra, S. 2002. Growth and yield attributes of finger millet as influenced by plant population and different levels of nitrogen and phosphorus. Indian Agriculturist, 46(1\&2): 65-71.

Seetharam, A. and Krishne Gowda, K.T. 2007. Production and utilization of small millets in India. Food uses of small millets and avenues for further processing and value addition, UAS, GKVK, Bangalore, pp. 1-9.

Suresh, A.P. 2013. "Integrated nitrogen management under different crop establishment methods in summer pearl millet (Pennisetum glaucum L.) under middle Gujarat condition" M.Sc. (Ag.) Thesis, Anand Agricultural University, Anand, Gujrat.

Uphoff, N., Marguerite, T., Devi, J., Behera, D., Verma, A. K and Pandian, B.J. 2011. National Colloquium on System of Crop Intensification (SCI). In: http://sri.ciifad.cornell. edu/aboutsri/othercrops/index.html.

Veeranna, G. and Reddy, P.R.R. 2010. Performance of System of Rice Intensification (SRI) under different planting geometry and age of seedlings. Andhra Agricultural Journal, 57(4): 397-399. 